Institut für Makroökonomie und Konjunkturforschung Macroeconomic Policy Institute

\title{
The theory of global imbalances: mainstream economics vs. structural Keynesianism
}

\author{
August 2014
}

\begin{abstract}
Prior to the 2008 financial crisis there was much debate about global trade imbalances. Prima facie, the imbalances seem a significant problem. However, acknowledging that would question mainstream economics' celebratory stance toward globalization. That tension prompted an array of explanations which explained the imbalances while retaining the claim that globalization is socially beneficial. This paper surveys those new theories. It contrasts them with the structural Keynesian explanation that views the imbalances as an inevitable consequence of neoliberal globalization. The paper also describes how globalization created a political economy that supported the system despite its proclivity to generate trade imbalances.
\end{abstract}

\section{Keywords}

global imbalances, saving glut, new Bretton Woods, asset shortage, structural Keynesianism.

Jel references

JEL references: F02, F32, F33.

1 Senior Economic Policy Advisor, AFL-CIO, Washington DC. 
The theory of global imbalances: mainstream economics vs. structural Keynesianism ${ }^{1}$

\begin{abstract}
Prior to the 2008 financial crisis there was much debate about global trade imbalances. Prima facie, the imbalances seem a significant problem. However, acknowledging that would question mainstream economics' celebratory stance toward globalization. That tension prompted an array of explanations which explained the imbalances while retaining the claim that globalization is socially beneficial. This paper surveys those new theories. It contrasts them with the structural Keynesian explanation that views the imbalances as an inevitable consequence of neoliberal globalization. The paper also describes how globalization created a political economy that supported the system despite its proclivity to generate trade imbalances.
\end{abstract}

Keywords: global imbalances, saving glut, new Bretton Woods, asset shortage, structural Keynesianism.

JEL references: F02, F32, F33.

Thomas I. Palley

Senior Economic Policy Advisor, AFL-CIO

Washington DC

Mail@thomaspalley.com

August 2014

\title{
1. Introduction
}

One of the most debated issues prior to the financial crisis of 2008 was the issue of global trade imbalances. Prima facie, the imbalances appear to be a significant problem. However, acknowledging that would question the mainstream economics’ celebratory stance toward globalization. This tension prompted an array of explanations seeking to explain the imbalances while retaining the claim that the existing model of neoliberal globalization is good for all.

This paper provides a survey and critique of the new theories. It also contrasts the new theories with the structural Keynesian explanation (Palley, 2007/08, 2012a, 2012b) which explains the global imbalances as an inevitable consequence of the neoliberal model of

\footnotetext{
${ }^{1}$ This paper was presented at the XI International Colloquium held at the Rio Branco Institute of Itamaraty (the Brazilian Foreign Ministry) on May 6-7, 2014 in Brasilia, Brazil. The colloquium was titled "Global crisis and the need for paradigm change".
} 
globalization. According to structural Keynesian theory there is both a supply- and demand-side to the global imbalance problem. The supply-side reflects the new production paradigm that underlies neoliberal globalization. The demand-side reflects the Keynesian theory of hegemonic currencies (Palley, 2006, 2012c). It also involves political economy that explains how policy facilitated the emergence of these new global supply and demand arrangements.

\section{What are the global financial imbalances?}

The global financial imbalances essentially concern the US trade deficit, which equals the trade surplus of the rest of the world. Table 1 provides a decomposition of the US goods trade deficit in 2007, the peak year of the last business cycle prior to the Great Recession. The table shows that in 2007 the US ran large trade deficits with all the leading economic regions.

Table 1. A decomposition of the US goods trade deficit in 2007 ( $\$$ billions).

\begin{tabular}{|l|l|l|}
\hline & \$ billions & Percent (\%) \\
\hline Total & -808.8 & 100 \\
\hline Pacific Rim & -372.3 & 46.0 \\
\hline China & -258.5 & 32.0 \\
\hline Canada \& Mexico & -143.0 & 17.7 \\
\hline Europe an Union & -110.2 & 13.6 \\
\hline OPEC & -117.2 & 14.5 \\
\hline Other & 192.4 & 23.8 \\
\hline
\end{tabular}

Source: Census Bureau.

On the other side of the ledger there are several countries that run persistent large trade surpluses. These countries have adopted what is often referred to as the export-led growth model, and they include Germany, Japan, China, Taiwan, and South Korea. In a sense, there is a co- 
dependence between the US economy and export-led growth economies, with the US providing the demand that fuels the latter's growth by providing orders for their factories and the incentive to invest more.

Figure 1 provides a simplified representation of the global economy which is decomposed into three components: the US economy, balanced trade economies, and export-led economies. The US runs a trade deficit with both the balanced trade and export-led economies, while the export-led economies run a surplus with the balanced trade economies. The net position is that the US has a trade deficit, the export-led economies have a trade surplus, and the balanced trade economies have approximate trade balance.

Figure 1. A simplified representation of the global imbalances.

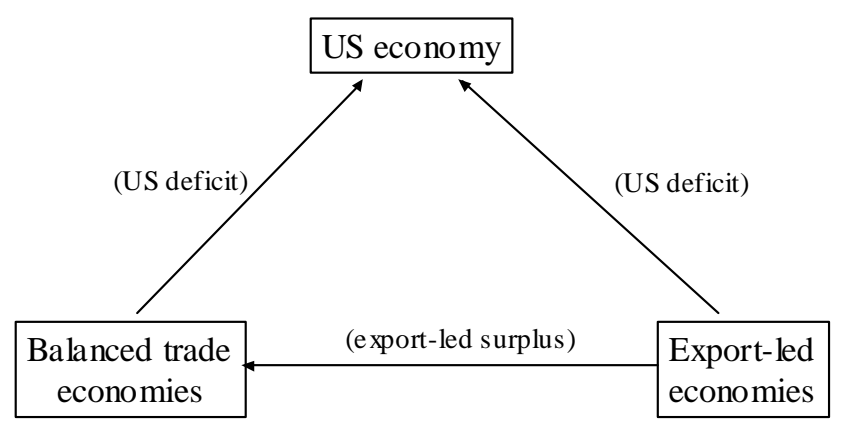

In terms of Table 1, after stripping out the OPEC oil trade deficit, the export-led economies account for 60 percent of the US non-oil trade deficit. The export led-economies can be roughly identified with the Pacific Rim group (which includes China) and the European Union (whose aggregate trade surplus is substantially explained by Germany). Additionally, Canada and Mexico constitute a NAFTA group. Mexico has an export-led relationship with the US, even though its overall economy is not export-led in the sense of generating persistent large 
trade surpluses. If Mexico is reclassified as being export-led with regard to the US, then the share of the US non-oil trade deficit accounted for by the export-led group (Pacific Rim, Germany, and Mexico) rises to approximately 70 percent.

Germany and Japan have been export-focused economies for decades. In the late 1970s they were joined by the four East Asian tiger economies - Hong Kong, Taiwan, South Korea and Singapore. Since then, others have jumped on the export-led bandwagon, particularly China and Mexico. Viewed in this light, the global imbalances are the product of a massive US trade deficit paired with the large trade surpluses of the export-led economies. The challenge is to explain that configuration.

\section{Mainstream economics and the problem of trade deficits}

The array of mainstream explanations of the global imbalances should be understood as part of an on-going theoretical response to the contradictions produced by globalization. The one constant across these explanations is that none question the claim of large benefits from neoliberal globalization.

Figure 2 illustrates the evolution of the mainstream approach to trade and the global imbalances. Stage 1 of mainstream thinking consisted of traditional static comparative advantage theory that argues trade brings benefits for all except in a few rare theoretical pathological instances that are empirically irrelevant. ${ }^{2}$ This was the original justification for globalization that was invoked in the late 1970s, and it continues to be invoked and serves as an ideological litmus test. All theories of global imbalances are required to be consistent with this comparative advantage argument of "benefits for all”.

\footnotetext{
${ }^{2}$ The pathologies concern the effect of trade opening on the terms of trade and growth (Johnson, 1954, 1955; Bhagwati, 1958). Mainstream economists dismiss such effects. The findings of Prebisch (1950) and Singer (1950) regarding secular declines in the terms of trade of commodity exporters question that dismissiveness.
} 
Figure 2. The mainstream approach to trade and global imbalances.

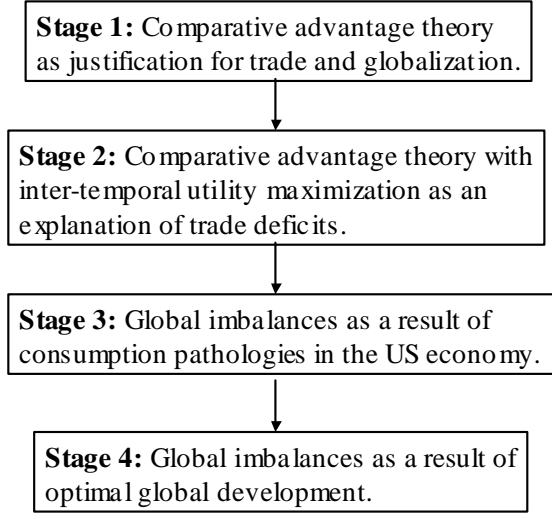

Stage 2 theory seeks to explain why globalization may be accompanied by trade deficits and yet still be good. Conventional Ricardian comparative advantage theory is a theory of balanced trade. However, globalization seems to produce trade deficits, and trade deficits also tend to be undesirable from the perspective of Keynesian macroeconomic theory because they constitute a demand leakage.

Stage 2 theorizing (Buiter, 1981; Obstfeld, 1982; and Svenson and Razin, 1983) aimed to explain deficits and blunt the Keynesian critique. It did so by simple mechanical transformation that extended the single period Ricardian model to a multi-period inter-temporal context. Persistent trade deficits can arise because of differences in country optimal inter-temporal consumption profiles.

Stage 3 constituted an extension of stage 2 and sought to explain the large US trade deficits of the 1980s and 1990s. The problem with the US was that it had a middle-aged population profile. According to stage 2 trade theory it should therefore have been running trade surpluses to build up saving in advance of population aging, but it was running large persistent trade deficits. Stage 3 theory therefore explained the deficit as the result of consumption 
pathologies in the US. The first stage 3 explanation was the twin deficits hypothesis of the 1980s that explained the trade deficit as due to the budget deficit. The second stage 3 explanation was the saving shortage hypothesis that explained the trade deficits as due to pathologically low saving rates by US households.

Unfortunately, as discussed below, stage 3 explanations proved inadequate. That prompted stage 4 theory which is the latest stage. The key theoretical twist is to explain the US trade deficit as an exchange of goods for financial assets. The supposed logic is that the US has comparative advantage in the production of financial assets while developing countries have a shortage of financial assets. This reinterprets the global imbalances as the product of a mutually beneficial exchange of goods for financial assets. Stage 4 theory therefore explains the global imbalances, while maintaining the claim that globalization is a mutually beneficial process.

\section{Stage 3 and 4 mainstream theory}

Figure 2 shows the plethora of mainstream explanations that have been advanced to explain the US trade balance and global imbalances. Stage 3 theory is associated with the period 1980-2000 and it produced the twin deficits and saving shortage hypotheses. Stage 4 theory is associated with the period 2000-2007 and it produced the Bretton Woods II (BW II), dark matter, saving glut, asset shortage, and reserve currency hypotheses. 
Figure 3. Mainstream explanations of the US trade deficit and global financial imbalances.

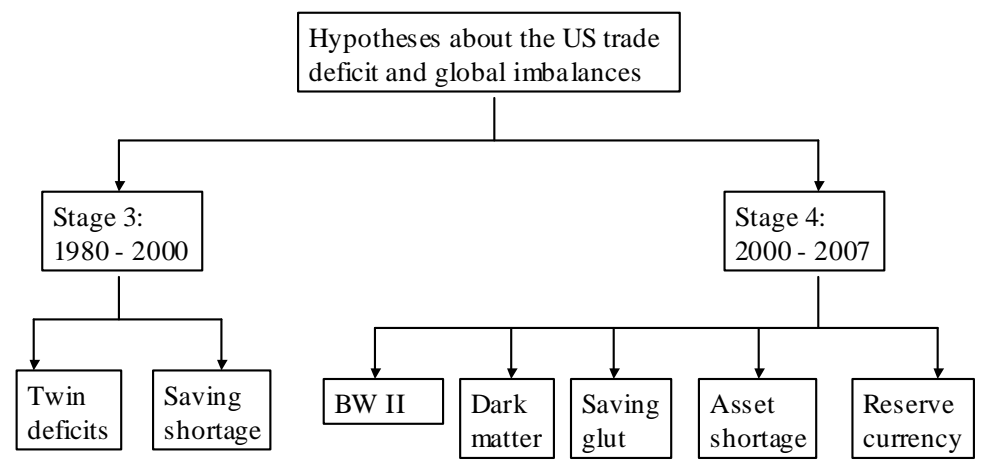

The twin deficits hypothesis maintains the US trade deficit is due to the US budget deficit. It reflects mainstream concern with the Reagan budget deficits of the 1980s (Feldstein, 1986). It fell out of favor with the Clinton budget surpluses of the late 1990s that were accompanied by record trade deficits. Japan and Germany also disproved it as they ran large trade surpluses in the 1990s along with persistent large budget deficits.

The saving shortage hypothesis was popular in the 1990s and replaced the twin deficits hypothesis. It maintains that the US trade deficit was the result of a low US household saving rate (i.e. excessive consumption). It reflects the 1990s US economic boom that saw a further decline in US household saving rates. The decline was rationalized on the grounds of a "new economy” with faster productivity growth driven by computer technology that augured higher future income. However, it fell out of fashion in the 2000s with the bursting of the "new economy” bubble, which was followed by continuing large US trade deficits combined with aggregate demand shortage that required the Federal Reserve to lower interest rates to record lows to spur economic recovery. 
The BWII hypothesis (Dooley et al., 2003, 2004) was the first stage 4 hypothesis. It argues globalization has created a new world in which emerging markets are industrializing. As part of this process they need to acquire hard assets which provide collateral against foreign direct investment (FDI) in those economies. This situation has supposedly created a parallel with the Bretton Woods arrangement that ruled from 1945 - 1971. Back then the US was the dominant global economy, and in the late 1950s it started running trade deficits as the rest of the world accumulated dollar balances that were needed to finance growing global trade. Now, the U.S. is again running large systematic trade deficits. The claim is that it is to provide collateral that can assist the industrialization of emerging market economies.

The dark matter hypothesis (Hausmann and Sturzenegger, 2005) maintains the US trade deficit reflects the US's ability to run a persistent trade deficit because of its superior returns on its foreign direct investments. These super-normal returns mean the US trade deficit is nothing to worry about. The deficit is an equilibrium outcome driven by US total income flows.

The saving glut hypothesis (Bernanke, 2005) maintains the US trade deficit is the result of excessive saving by China. The argument is China is running trade surpluses owing to its export-led growth strategy based on an undervalued currency. That undervaluation is maintained by recycling China’s trade surpluses back to the US via purchases of US financial assets, particularly government bonds. According to the argument, the US actually reaps large benefits as China’s recycling drives down US interest rates. In effect, China provides subsidized borrowed resources that can be used to further US growth. Problems only arise if US financial markets misallocate that credit.

The asset shortage hypothesis (Caballero, 2006, 2007) maintains that the world economy is suffering from a shortage of high quality financial assets owing to increased asset demand 
caused by rising global income due to globalization. It asserts the US has a comparative advantage in producing high quality financial assets, so that the US trade deficit is the product of a new application of comparative advantage whereby the US trades financial liabilities for goods.

Lastly, the dollar reserve currency hypothesis (Bibow, 2008; Lago et al., 2009) argues that, after the East Asian financial crash of 1997, EM economies started running trade surpluses to acquire dollar reserves to protect against future financial crises. At the theoretical level, the reserve currency hypothesis is the most complicated and ambivalent. At its base, there is a problem with the international financial system that compels EM economies to engage in excessive foreign reserve accumulation. In a neoclassical model this need to acquire reserves produces large seignorage benefits for the US. However, in a Keynesian framework it promotes beggar-thy-neighbor export competition that contributes to global demand shortage.

The purpose of stage 4 theory is to explain the global imbalances in a manner that is consistent with the claim that globalization delivers benefits for all. Stage 4 theory also seeks to explain why “capital flows north” (i.e. why the US runs trade deficits while EM economies run trade surpluses), which is contrary to conventional microeconomic trade and development theory that predicts the reverse. According to conventional theory, capital should flow from capitalabundant rich countries (i.e. the U.S.) to capital-scarce poor countries (i.e. emerging markets) because rates of return are higher in capital scarce economies owing to the relative scarcity of capital. Prima facie, the global imbalances contradict that prediction and require explanation or else conventional theory must be jettisoned.

The BW II, dark matter, saving glut, and asset shortage hypotheses all explain the existence of global imbalances. Furthermore, they all argue the imbalances are benign or even benevolent. The US is either taking advantage of its comparative advantage in production of 
financial assets; or taking advantage of its comparative advantage in investing; or benefitting from the willingness of EM countries to accumulate US financial liabilities and thereby provide the US with subsidized resources. According to all four hypotheses the global imbalances enhance US economic welfare, implying existing trade and globalization policy should be continued. All therefore explain the global imbalance in a way that cheerleads for neoliberal globalization and rationalizes policymaker indifference to the trade deficit.

\section{Critique of stage 4 theory}

\section{5. a Critique of the BW II hypothesis}

The first and most fundamental criticism of the BW II hypothesis is lack of evidence for its core argument. There is absolutely no evidence of East Asian countries pledging their foreign exchange reserves as collateral for FDI. A second criticism is there are absolutely no empirical grounds for an analogy between current economic patterns and the patterns that characterized the BW I era (1945-1971). In the BWI era the US ran small surpluses that eventually turned into small trade deficits, had a growing manufacturing sector, and had rising real wages. In contrast, during the BWII (1980 - today) era the US has had large and growing trade deficits, a shrinking manufacturing sector, and stagnant real wages.

5.b Critique of the saving glut hypothesis:

The first major flaw in the saving glut hypothesis concerns its loanable funds approach to financing of trade deficits. That approach misrepresents China as financing the US trade deficit. This explains why, before the financial crisis of 2008, policymakers and economists viewed the main danger as an exchange rate crash and an interest rate spike resulting from China withdrawing its willingness to finance the deficit. That never happened because the loanable funds approach is wrong. 
As shown in Figure 3, the US initiates financing of its trade deficit. The first transaction is between US borrowers and US banks which provide money to households (money 1). Households then buy goods from China with that money (money 2), and China then buys U.S financial assets (money 3). The important feature about Figure 3 is that the system can break down in either the domestic credit market or the market for financial assets. The BW II hypothesis and mainstream economists focused on a sudden-stop of financial asset purchases by China. Structural Keynesians (Palley, 2007/8) focused on a sudden stop in the domestic credit market and were right because that is what happened.

Figure 4. The structure of transactions governing U.S. China/East Asia trade.

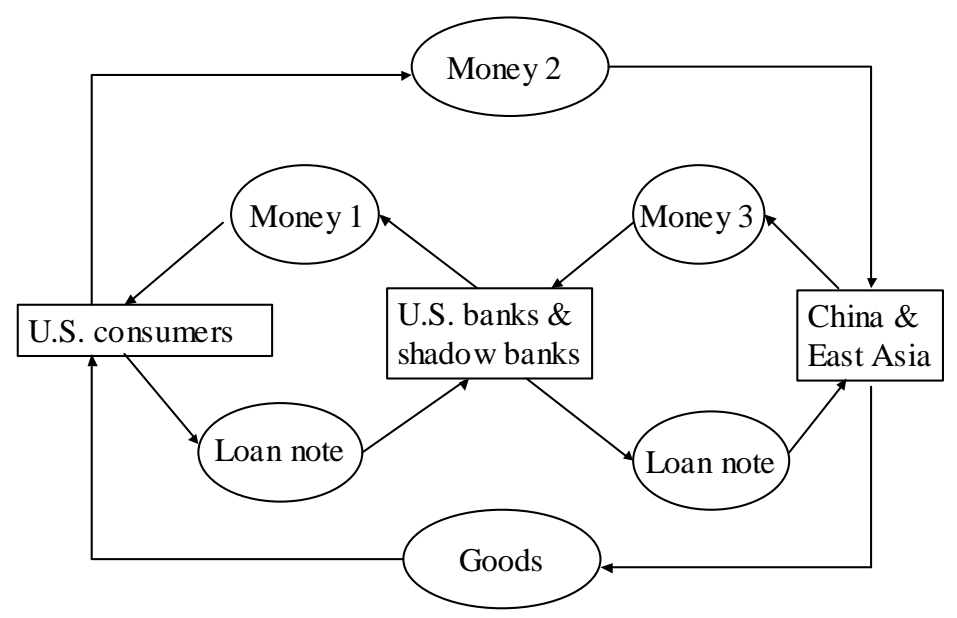

A second flaw is the characterization of China's trade surplus as due to excessive saving. That characterization misunderstands the microeconomics of global production. In fact, China's export capacity has been created by multi-national corporations shifting production facilities to China. This is shown in Table 2. In 2005, over fifty percent of Chinese exports were produced by 100 percent foreign owned companies, and over 76 percent of China’s exports are produced by foreign owned companies or joint-venture companies. 
Table 2. Decomposition by firm ownership of the structure of

Chinese exports in 2005.

Source:Manova and Zhang, 2008

\begin{tabular}{|l|l|l|l|l|l|}
\hline & All firms & $\begin{array}{l}\text { Foreign- } \\
\text { owned }\end{array}$ & $\begin{array}{l}\text { Joint } \\
\text { ventures }\end{array}$ & $\begin{array}{l}\text { Private } \\
\text { domestic }\end{array}$ & $\begin{array}{l}\text { State- } \\
\text { owned }\end{array}$ \\
\hline Exports & $100 \%$ & 50.4 & 26.3 & 13.1 & 10.3 \\
\hline
\end{tabular}

The saving glut hypothesis misunderstands both the monetary macroeconomics and the microeconomics of global production. It does not criticize trade and globalization, and according to its logic the US actually benefits from access to subsidized Chinese saving. Problems only arise if the US misuses that saving in unproductive speculative activity. Lastly, the saving glut hypothesis confuses understanding by creating a pseudo-Keynesian discourse about saving gluts when it has nothing to with Keynesian demand shortage.

\section{5.c Critique of the asset shortage hypothesis}

The asset shortage hypothesis (Caballero, 2006, 2007) is a first cousin of the BWII hypothesis. It argues emerging market (EM) economies run trade surpluses to accumulate financial wealth which the US has comparative advantage producing. Additionally, there is a global asset shortage which drives up asset prices and explains asset bubbles. Furthermore, asset price bubbles are to be welcomed as they encourage production of high quality financial assets to fill the asset shortage.

What's wrong with this? First, the hypothesis has no understanding of the fact that EM trade surpluses are due to the new global production structure created by multi-national corporations. Second, there are better explanations (Palley, 2007a; 2012a, p.114) for increased 
asset prices such as increased income inequality; the increase in the profit share; lower taxes on capital; lower interest rates; credit market innovation that has increased the supply of credit to buy assets; and simple investor mania. Third, it is also highly doubtful that there is an asset shortage as financial innovation has increased the supply of financial liabilities.

\section{5.d Critique of the reserve currency hypothesis}

The final stage 4 explanation is the reserve currency hypothesis. Its logic is also questionable. First, it also fails to recognize the new structure of global production that is at the core of the global imbalance problem. Second, it fails to recognize that the problem of the US trade has been long-running, dating back to 1980, and began long before the East Asian financial crisis. Third, the reserve currency hypothesis argues countries are accumulating foreign exchange reserves to protect against financial crisis caused by capital flight. However, reserve accumulations have now gone far beyond what can be economically justified by the most risk-averse disposition, which suggests the real reason is something different.

\section{The structural Keynesian explanation of global imbalances}

The defining feature of stage 4 theories is that they aim to explain the global imbalance problem while maintaining that globalization is good. The structural Keynesian hypothesis (Palley, 2007/08, 2012a, 2012b) provides a totally different explanation that sees global imbalances as the inevitable product of neoliberal corporate globalization. And rather than being beneficial, the imbalances are a serious problem.

Table 3 shows the U.S. trade balance by business cycle peak year for the period 1960 2007. From 1960 to 1980 US trade was roughly in balance. After 1980, the US started running steadily increasing trade deficits that reached 5.7 percent of GDP in 2007. The critical feature of 
Table 3 is that it shows that the US trade deficit has been a long-evolving issue, and there was a break around 1980 that reflects the advent of the neoliberal era.

Table 3. The U.S. goods \& services trade deficit by business cycle peaks, $1960-2007$.

Sources: Economic Report of the President, 2009 and author's calculations.

\begin{tabular}{|l|l|l|l|}
\hline Peak year & $\begin{array}{l}\text { Trade deficit } \\
\text { (\$ millions) }\end{array}$ & $\begin{array}{l}\text { GDP } \\
\text { (\$ billions) }\end{array}$ & $\begin{array}{l}\text { Trade deficit/ } \\
\text { GDP (\%) }\end{array}$ \\
\hline $\mathbf{1 9 6 0}$ & 3,508 & 526.4 & 0.7 \\
\hline $\mathbf{1 9 6 9}$ & 91 & 984.6 & 0.0 \\
\hline $\mathbf{1 9 7 3}$ & 1,900 & $1,382.7$ & 0.1 \\
\hline $\mathbf{1 9 8 0}$ & $-25,500$ & $2,789.5$ & -0.9 \\
\hline $\mathbf{1 9 8 1}$ & $-28,023$ & $3,128.4$ & -0.9 \\
\hline $\mathbf{1 9 9 0}$ & $-111,037$ & $5,803.1$ & -1.9 \\
\hline $\mathbf{2 0 0 1}$ & $-429,519$ & $10,128.0$ & -4.2 \\
\hline $\mathbf{2 0 0 7}$ & $-819,373$ & $13,807.5$ & -5.9 \\
\hline
\end{tabular}

Figure 4 shows how the international economy in the post-World War II era can be characterized by three different regimes. From 1945-1979 there was a free trade regime, associated with the GATT and declining tariffs. That era ended with the completion of the Tokyo GATT round in 1979. The free trade regime was followed by a corporate globalization regime that shaped policy from 1980 to 2000, and that regime was then supplanted by the current Chinacentric globalization regime (Palley, 2012d).

Figure 4. The evolving political economy of the international economy.

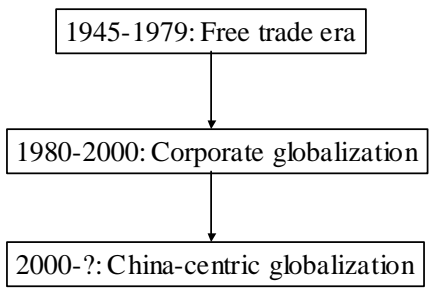


6. a Barge economics: why globalization is different from free trade

The starting point for the structural Keynesian perspective is the recognition that globalization is a different phenomenon than free trade. The critical change is increased international mobility of means of production (capital and technology) resulting from improvements in transportation, communication, and ability to manage globally diversified production networks. This created the possibility of a new global production zone model configured on the principle of global cost arbitrage.

The new model can be labeled "barge economics" (Palley, 2007b) because it is as if factories are placed on barges that float between countries to take advantage of lowest costs which can be due to under-valued exchange rates, low taxes, subsidies, absence of regulation, or abundant cheap exploitable labor. Trade remains central because goods must cross borders and hence the need for trade agreements. However, barge economics is fundamentally different from comparative advantage trade theory. Free trade is about cross-border exchange of goods and services but production is immobile. Globalization is about creating flexible international production networks configured on the principle of global cost arbitrage. This difference is reflected in the policy debate. The original trade debate was about taking down tariff barriers. Now, the debate is about property rights and investor protection. Unfortunately, this simple but essential insight regarding the difference between trade and globalization is obscured because orthodox economics asserts globalization is merely an extension of comparative advantage theory which motivated the free trade era.

\section{6.b The US economy and the evolution of neoliberal globalization}

The 1980s were a period of corporate experimentation with mobile production and negotiation of the legal framework that would govern the global production zone model. The early 1980s shift 
of manufacturing within the US from the "rust belt" to the "sun belt" was a precursor to fullscale globalization. The new model then took off in the 1990s and there were three critical stages:

-Stage 1: North American Free Trade Agreement (NAFTA) in 1994.

-Stage 2: Strong dollar policy put in place after East Asia financial crisis of 1997.

-Stage 3: China permanent normal trade relations (PNTR) in 2000.

The inauguration of NAFTA in 1994 represents a major historical event that fused the US, Canada, and Mexico into a unified production zone. Its historical importance is that it joined developed and developing economies for the first time, thereby establishing the template corporations wanted. In doing so, NAFTA changed the significance of exchange rates which had previously mattered largely for trade. Now, they mattered for location of production. It also changed the attitude of US multinational corporations to exchange rates, which shifted in favor of a strong dollar because that lowered the price of imported products and raised profit margins on imported production. Lastly, NAFTA created a precedent for strong dollar policy because the US accepted peso devaluation as a means of addressing the 1994 Mexican financial crisis.

The effects of NAFTA on the US trade balance with Mexico are shown in Table 4. Before NAFTA the US had a small trade surplus with Mexico: after NAFTA, the trade balance turned to deficit and continued increasing thereafter. Within the US economy, manufacturing plants were closed and production and investment were diverted to Mexico. The threat of shifting jobs to Mexico was also used to suppress wages and batter unions (Bronfenbrenner, 2000; Bronfenbrenner and Luce, 2004). 
Table 4. US goods trade balance with Mexico before and after NAFTA (\$ billions)

Source: Census Bureau.

\begin{tabular}{|l|l|l|l|l|l|l|l|l|}
\hline 1991 & 1992 & 1993 & 1994 & 1995 & 1996 & 2000 & 2005 & 2007 \\
\hline 2.1 & 5.4 & 1.7 & 1.3 & -15.8 & -17.5 & -24.5 & -49.7 & -74.6 \\
\hline
\end{tabular}

The second stage of implementation of globalization was the strong dollar policy adopted after the East Asian financial crisis of 1997. US policymakers followed the precedent of the 1994 peso crisis, making large dollar loans to crisis countries and accepting large exchange rate depreciations by those countries. This policy was strongly supported by US multinational corporations which were looking to offshore and outsource production. The strong dollar policy thereby created a permanent incentive for US corporations to downsize their US manufacturing operations and increase their foreign manufacturing operations. The policy was also supported by EM economies because it spurred export-led growth and increased their attractiveness for FDI.

Table 5 shows the results for the US trade deficit with Pacific Rim countries which worsened dramatically. US manufacturing was also put into recession in 1998, two years before the economy went into recession. Lastly, the new policy effectively made the US consumer the global buyer of first and last resort. That rendered the global economy dependent on the US consumer, which explains why the global economy has become so vulnerable to US economic crashes. 
Table 5. US goods trade balance with Pacific rim countries (\$ billions). Source: Census Bureau.

\begin{tabular}{|l|l|l|l|l|l|}
\hline 1995 & 1996 & 1997 & 1998 & 1999 & 2000 \\
\hline-108.1 & -101.8 & -121.6 & -160.4 & -186.0 & -215.4 \\
\hline
\end{tabular}

The third critical stage in the making of the current global system was granting China permanent normal trading relations (PNTR) in 2000 which opened the way for China's admission into the World Trade Organization in 2001. PNTR gave China permanent access to the US market without effective safeguards against large trade deficits and without defense against China's undervalued exchange rate policies, while WTO admission secured China’s agreement to respect investments in China. PNTR therefore cemented the structure of globalization that corporations wanted by making China part of the global production zone, thereby inaugurating the era of China-centric globalization.

As with NAFTA and the adoption of strong dollar policy after the East Asian crisis of 1997, the passage of China PNTR triggered a surge in the US bilateral trade deficit. This surge is shown in Table 6. There were also significant real impacts on the US economy. Corporate profits increased as a result of ability to source from China, while the impact on US manufacturing jobs and manufacturing investment was disastrous. Corporations closed existing plants which were relocated to China, and new investment was also diverted to China. This explains why manufacturing employment fell continuously during the business cycle expansion of 2001 - 
2007 and why investment spending was so weak over the cycle. That combination contributed to broad macroeconomic weakness that compelled the Federal Reserve to keep interest rates at historically low levels, thereby helping foster the housing bubble that laid the foundation for the financial crisis of 2008. Lastly, there were also negative effects on Mexico and other developing countries as China siphoned off FDI that they would previously have received. Furthermore, since China was now the global low cost producer, there was also relocation of some multinational manufacturing activity from other EM countries to China in accordance with the principles of barge economics.

Table 6. US goods trade balance with China before and after PNTR (\$ billions) Source: Census Bureau.

\begin{tabular}{|l|l|l|l|l|l|l|l|l|}
\hline 1998 & 1999 & 2000 & 2001 & 2002 & 2003 & 2004 & 2005 & 2007 \\
\hline-56.9 & -68.7 & -83.9 & -83.1 & -103.1 & -124.1 & -161.9 & -201.5 & -256.2 \\
\hline
\end{tabular}

6.c Economic analysis of the impact of neoliberal globalization on the US economy The economic impact of globalization on the US economy is illustrated in Figure 6 which shows US supply and demand for tradeable goods. The supply curves $\mathrm{S}_{\mathrm{US}, 2007}$ and $\mathrm{S}_{\mathrm{FOREIGN,2007}}$ show the actual supply of tradable goods to the US in 2007. The supply curves $\mathrm{S}_{\mathrm{US}}$, ALT and $\mathrm{S}_{\text {FOREIGN,ALT }}$ are alternative "counter-factual” supply curves constructed on the basis as if US economic policy had remained unchanged after 1980 so that US and global manufacturing had developed along pre-neoliberal globalization lines. After 1980, globalization promoted deindustrialization that persistently shrank the US manufacturing base, contributing to a leftward rotation of the US 
tradeable goods supply curve. It also shifted manufacturing production to EM economies which rotated the foreign tradeable goods supply curve right. As a result, US now runs large structural trade deficits.

Figure 5. The effect of globalization on the global supply of tradeable goods to the U.S. and on U.S. demand for and supply of tradeable goods.

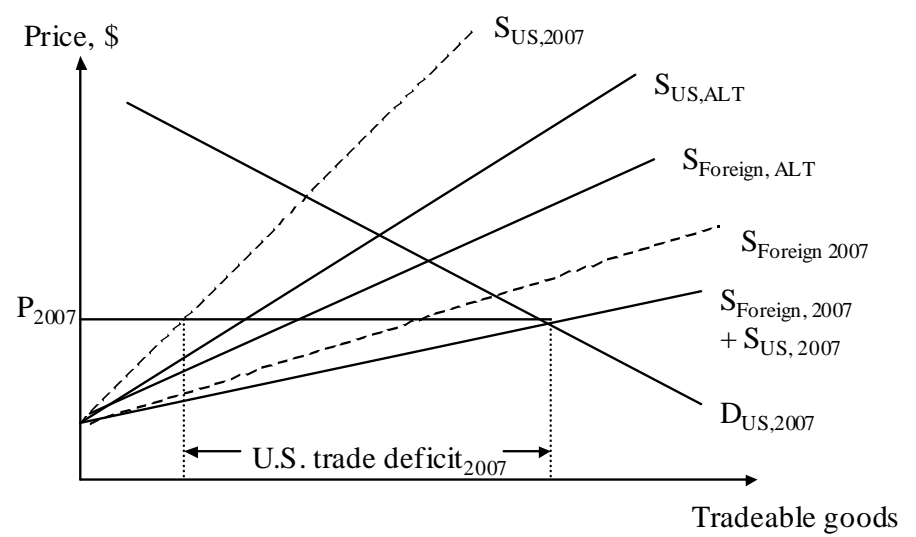

\section{6.d The demand side of the structural Keynesian explanation}

Barge economics explains supply-side developments produced by globalization. The demand side is explained by the fact that global purchasing power is significantly concentrated in the northern economies (especially the US), while EM economies have not developed their own systems of domestic demand generation. Consequently, EM economies need to sell to the US and rely on export-led growth.

That also explains why EM economies are willing to accumulate US financial assets and dollar reserves. It is not an issue of shortage of financial assets or EM inability to produce financial assets. Instead, EM economies need undervalued currencies to remain internationally competitive in world crowded with other EM economies looking to export and continuing productivity growth in north. 


\section{6.e The structural Keynesian theory of hegemonic currencies}

The above structural Keynesian framing of the demand side connects with the Keynesian theory of hegemonic currencies (Palley, 2006, 20012c) which explains why the global economy has become so reliant on the dollar, the source of the US's ability to collect global seignorage via its trade deficit, and the role of the dollar in financing global imbalances.

The US dollar is the world's premiere currency, with approximately two-thirds of world official foreign exchange holdings being dollars. Moreover, many countries have been willing to run sustained trade surpluses with the US, supplying everything from t-shirts to Porsches in return for additional dollar holdings. The Keynesian theory of hegemonic currencies explains why countries are willing to exchange valuable resources for dollar IOUs.

The conventional explanation of the dollar's reserve currency status is a "medium of exchange” story. The US has historically been the largest and richest currency area, with the largest share of world output and trade. This has provided incentives for other countries to hold and use dollars. Additionally, the fact that many governments over-issue their own money and create high inflation, encourages foreign citizens to protect themselves by holding dollars instead of domestic currency.

A second theory of reserve currencies, associated with the political left, is based on US military power and the Pax Americana. The argument is that US military power provides the security that protects the global market system, and New York is the new Rome. Countries, such as Saudi Arabia, hold reserves in dollars because New York is a political safe haven, and because that is how they help cover the costs of enforcing the Pax Americana.

The Keynesian theory of hegemonic reserve currencies provides a third explanation. Put simply, countries transfer real resources to the US through their trade surpluses because of their 
failure to generate adequate consumption spending in their own markets, be it due to poor income distribution or bad domestic economic policies. This forces them to rely on the American consumer.

The logic of the Keynesian theory of hegemonic currencies is easily illustrated. Over the past three decades, the demand side of the global economy has been supported by robust growth of US consumer spending. This spending increased imports, absorbing the expanding production of EM economies. The EM economies (especially East Asian and China) were willing to accept dollars and run trade surpluses with the U.S. because exports kept their factories operating and export success attracted further FDI that advances development. Additionally, under-valued exchange rates have been a vital part of this strategy as it keeps exports competitive. EM countries therefore channeled their trade surpluses into dollar denominated assets, keeping the dollar over-valued and enabling them to sell their exports in the U.S. market. That structure explains both the continuing strong demand for dollars despite the U.S. trade deficit and the dollar’s dominance in official foreign exchange holdings.

Ironically, according to the Keynesian theory of hegemonic currencies, the US's dispensation from trade deficit discipline stems from other countries' failure to develop an equivalent of the American consumer. Countries want to industrialize with full employment, but they lack adequate internal demand. Consequently, they must rely on the US market. It is also why Germany supplies BMWs and Mercedes-Benzes in return for dollar IOUs.

Conventional neoclassical theory says the dollar will only lose its dominance when countries' portfolios become saturated with dollar holdings. At that stage they will cease buying and may even sell dollars, causing a fall of the dollar. The problem with this story is that countries have no incentive to sell dollars as this would kill the golden goose of export-led 
growth. The Keynesian theory of hegemonic currencies suggests a different take. The dollar will only be toppled if countries manage to develop their own domestic consumption. Euroland is most capable of doing this, but for the moment it is gripped by policymaking that is obsessed with inflation and afraid of growth. China needs to improve its income distribution in a way that links income distribution to productivity. Unions are the natural way to do this, but they are blocked by China's totalitarian political system that fears unions.

All three theories have merit, but in the current economic environment the Keynesian theory is especially relevant. As long as other countries fail to generate sufficient demand in their own markets, they will be compelled to rely on the US market and accumulate dollar denominated financial assets. However, none are well served by this co-dependence. Other countries are resentful of the US's special situation that exempts it from trade deficit discipline. Side-by-side, US long-term economic prospects are undermined by the erosion of the manufacturing sector, while US workers face wage and job pressures from imports that are competitively advantaged by the dollar's over-valuation.

6.f The structural Keynesian explanation of why capital flows north

The structural Keynesian hypothesis also explains why capital has flowed north (i.e. why developing countries have run trade surpluses), contrary to traditional trade theory. Traditional trade theory denies the existence of demand shortage problems and only recognizes supply shortage problems resulting from a world of scarcity. Given its marginal product logic, it can only explain why capital flows north by recourse to strange and unconvincing stage 4 theories. The structural Keynesian approach says EM economies have a demand shortage problem because they have not developed their domestic markets to absorb the massive increase in their productive capacities resulting from globalization. The supply shortage problem has been solved 
by multi-national corporations and barge economics. In effect, neoliberal globalization creates a division of labor where consumers are in the north, producers are in the south, and there is a demand shortage problem relative to productive capacity in the south. Investment flows south through FDI to take advantage of low costs of production, but the fruits of that investment (i.e. production) flows north. This reasoning is completely absent from orthodox economics.

An open question is the sustainability of this arrangement. That is because the globalization process contributes to gradually undermining median household income in developed economies (the North), thereby undermining the demand side of the system. Consequently, the system can gradually lose vitality and sink into stagnation as demand weakens. This can happen without financial crisis or abandonment of the dollar. As developed economy demand weakens, the global imbalances shrink but both developed an EM economies become increasingly tainted by stagnation.

Side-by-side, within EM economies the policy incentive is to suppress wage growth to maintain international competitiveness. That hinders the development of EM domestic demand to offset stagnating demand in the North.

Lastly, this configuration of developments and competitive pressures means the hegemony of the dollar likely remains intact. That is because EM countries have an incentive to keep their currencies undervalued to gain international competitive advantage, and that requires directing trade surpluses into dollar reserves to prevent currency appreciation.

\section{6.g The political economy of global imbalances}

Barge economics explains how globalization functions and why it generates trade imbalances. The other side of explaining the global imbalance problem concerns political economy and why policymakers permitted it. 
Within the US, pre-1980 economic policymaking was dominated by Keynesian logic and policymakers viewed trade deficits with concern as they represented a leakage of AD. After 1980, the position changed owing to the displacement of Keynesian economics by new classical macroeconomics which emphasizes the problem inflation over unemployment. This change meant policymakers started to view trade deficits as semi-virtuous because trade helped constrain inflation.

For big business, trade opening in the 1980s was viewed favorably as a means of disciplining industrial labor unions and reversing the profit squeeze of the late 1960s and 1970s. In the 1990s trade opening became part of the logic of creating a "global production zone" in which American firms could either source cheaper inputs or produce and export back to the US.

Both policymakers and business therefore came to see trade through the lens of costs and wages. For policymakers, trade openness became a means of constraining inflation. For business, trade openness was initially a means of disciplining workers, and it then became a central part of a strategy aimed at creating a global production zone organized on the principle of global cost arbitrage. This reconfiguration of understanding and the political dominance of business interests explain why the model was permitted to take hold. In the Keynesian era (1945 - 1979), trade was roughly balanced trade because policymakers were averse to large deficits for macroeconomic reasons. In the neoliberal era, policymakers have had no interest in constraining trade deficits and big business has actively benefitted from deficits.

As regards EM economies, there are several reasons why they adopted the new system. First, the new arrangements offered EM economies easier access to the US product market. Second, the relocation of production and diversion of investment spending to EM economies resulted in large transfers of modern productive capacity and managerial expertise. 
Third, EM support for US-led corporate globalization also reflects the global triumph of neoliberal economic policy. In the 1980s and early 1990s the IMF and World Bank used the financial leverage provided by the 1980s debt crisis to force neoliberal policy reforms. Those reforms included abandoning state-led development policies that used strategic protection. The economics profession provided support for IMF and World Bank policies by asserting a new consensus about the benefits of trade-openness and export-led growth (Palley, 2012d). This new consensus was justified by the economic success of the four East Asian tigers (South Korea, Hong Kong, Singapore, and Taiwan) which were held up as representative of what was possible.

Fourth, the new model of export-led growth based on FDI and undervalued currencies produced large trade surpluses for EM economies. Those surpluses helped relieve long-standing financial constraints on growth, providing another reason to adopt the model.

Putting the pieces together, it can be seen that neoliberal globalization created an economic structure that inevitably produced trade deficits and a global imbalance problem. Simultaneously, it also created a political economy structure that justified deficits, discouraged policy from reining in deficits, and supported a strong dollar policy that increased deficits. For US policy makers the strong dollar lowered inflation; for multinational corporations it kept the pressure on union labor and increased profits from foreign sourcing; and for EM economies it offered a pathway for development, which though distorted was relatively free of long-standing financial constraints.

\section{Conclusions: the difficulty of change despite globalization's failings}

Stage 4 theory is the latest evolution in mainstream economics thinking about international trade. It provides a family of hypotheses that aim to explain the US trade deficit and global imbalances as beneficial phenomena. In doing so, it reconciles the US trade deficit with the central 
intellectual tenets of mainstream economics regarding the benefits of free trade and globalization.

In sharp contrast, the structural Keynesian hypothesis explains the global imbalances as the predictable outcome of the policies associated with neoliberal globalization. Moreover, these policies are viewed as having contributed to the destruction of shared prosperity in the US. Though EM economies have benefitted so far, the model has created new problems and there are significant doubts about its sustainability. That means EM economies could face challenges ahead. EM economies are now are placed in a new form of South-South competition to attract FDI that produces distorted development that is excessively export-focused; produces wage suppression and increased inequality; and prevents governments from implementing needed social and environmental regulation and policies that are the hallmark of development that generates shared prosperity. EM economies are also reliant on multinationals to supply inputs, technology and managerial expertise, which makes countries more vulnerable to political sanction by MNCs. Furthermore, the entire model is vulnerable to stagnation that first infects the North and then spreads to the South. The reason is the model undermines the Northern consumer on whom it depends to provide demand. That renders the South vulnerable and it is unlikely it can develop its own consumer market because of South-South race-to-the-bottom pressures.

These failings speak to the need for planned change, but that is enormously difficult (one might say near impossible). EM economies have benefitted from the process so far and are therefore hesitant to challenge it on grounds that it "might" go wrong in the future. Policymakers who move to change the system also face severe disciplining. First, any country that signals a desire for change will be singled out for economic punishment by global corporations and 
Northern governments that retain committed to globalization. Second, the globalization has created economic and legal "lock-in” that is hard to reverse (e.g. treaties like NAFTA).

Another obstruction comes from the mainstream economics profession that strongly influences public understanding of and discourse about globalization. The economics profession has been a gung-ho supporter of neoliberal globalization, using the rhetoric of free trade. It advocated the policies of the Washington Consensus that were implemented by the IMF and World Bank in the 1980s and 1990s, and it remains one-hundred percent intellectually committed to neoliberal globalization. However, because globalization inevitably creates global imbalances which are potentially politically challenging, it is necessary to sanitize them by arguing they do no harm and do not undermine the benefits of neoliberal globalization. That is the political function of stage 4 theories global imbalances. The profession therefore promotes hypotheses that sanitize the imbalances, while ignoring those that paint the imbalances as the product of a toxic form of globalization.

Moving a globalization reform agenda requires getting the narrative and understanding right. That is the practical political economy significance of the arguments presented in this paper. 


\section{References}

Bernanke, B.S. [2005]: The global saving glut and the U.S. current account deficit, The Sandridge Lecture, Virginia Association of Economics, Richmond, VA., March 10.

Bhagwati, J., “Immizerizing Growth: A Geometrical Note,” Review of Economic Studies, 58 (1958), $201-5$.

Bibow, J. (2008): The international monetary (non-) order and the global capital flows paradox, Working Paper No.531, Levy Economics Institute of Bard College, April.

Bronfenbrenner, K. [2000]: Uneasy Terrain: The Impact of Capital Mobility on Workers, Wages, and Union Organizing, Report prepared for the United States Trade Deficit Review Commission, Washington, DC, September.

Bronfenbrenner, K., and Luce, S. [2004]: The Changing Nature of Corporate Global Restructuring: The Impact of Production Shifts on Jobs in the U.S., China, and Around the Globe, Report prepared for the U.S.-China Economic and Security Review Commission, Washington, DC October.

Buiter, W.H. [1981], "Time preference, international lending and borrowing in an over-lapping generations model,” Journal of Political Economy, 89, 769-797.

Caballero, R.J. [2006]: “On the Macroeconomics of Asset Shortages,” NBER Working Paper No.12753, December.

Highlights No. 1. [2007]: “Understanding Global Imbalances,” Economics at MIT: Research

Dooley, M.P., Folkerts-Landau, D., and Garber, P. [2003]: An essay on the revised Bretton Woods system, Working Paper 9971, Cambridge, MA: National Bureau of Economic Research, September.

Dooley, M.P., Folkerts-Landau, D., and Garber, P. [2004]: The US current account deficit and economic development: Collateral for a total return swap, Working Paper 10727, Cambridge, MA: National Bureau of Economic Research, August 2004.

Feldstein, M. [1986], “The budget deficit and the dollar," NBER Macroeconomic Annual, MIT Press, Cambridge, MA, September, 355-409.

Hausmann, R., and Sturzenegger, F. [2005]: Dark matter makes the US deficit disappear, Financial Times, December 7.

Johnson, H., "Increasing productivity, income-price trends and trade balance, Economic Journal, 64 (1954), $462-85$. 
-------------, "Economic expansion and international trade," Manchester School of Economic and Social Studies, 23 (1955), 95 - 112.

Lago, I., Duttagupta, R., and Goyal, R. (2009): The debate on the international monetary system, Strategy, Policy, and Review Department, International Monetary Fund, November 11.

Manova, K., and Zhang, Z. [2008]: China’s exporters and importers: Firms, products, and trade partners, unpublished manuscript, Department of Economics, Stanford University, CA, June.

Obstfeld, M. [1982] 'Aggregate spending and the terms of trade: Is there a Laursen-Metzler effect?’ Quarterly Journal of Economics, 97, 251-270.

Palley, T.I. [2006] "Why Dollar Hegemony is Unhealthy,” Yale Global Online, June $20^{\text {th }}$.

--------- [2007a], “World asset prices; what's really going on?” posted at www.thomaspalley.com, January $1^{\text {st }}$.

[2007b], “Jack Welch’s barge: the new economics of trade” posted at www.thomaspalley.com, October $1^{\text {st }}$.

Palley, T.I. [2007/8], “The fallacy of the revised Bretton Woods hypothesis: why today's system is unsustainable and suggestions for a replacement," International Journal of Political Economy, 36 (Winter), p. 36 - 52. Originally published as Public Policy Brief No. 85, The Levy Economics Institute of Bard College, 2006.

[2012a] From Financial Crisis to Stagnation: The Destruction of Shared Prosperity and the Role of Economics, Cambridge: Cambridge University Press, February.

[2012b], "Explaining global financial imbalances: A critique of the saving glut and reserve currency hypotheses," From Crisis to Growth: The Challenge of Debt and Imbalances, Metropolis - Verlag, Marburg: Germany, p. 145-168.

------------- [2012c] “A Keynesian Theory of Hegemonic Currencies - Or Why the World Pays Dollar Tribute," posted at www.thomaspalley.com, August $9^{\text {th }}$.

-------------- [2012d] “The rise and fall of export-led growth,” Investigacion Economica, LXX, 280 (Abril - Junio de 2012), 15 - 35. Originally published as Public Policy Brief No. 119, The Levy Economics Institute of Bard College, 2011.

------------ [2013] “The perils of China-centric globalization,” Journal of International Security Affairs, 25 (Fall/Winter), $11-18$.

Prebisch, R. [1950], "The economic development of Latin America and its principal problems," Economic Bulletin for Latin America, 7, 1-12. 
Singer, H., "The distribution of gains between investing and borrowing countries," American Economic Review, Papers and Proceedings, 1950.

Svenson, L.E.O. and A. Razin [1983], "The terms of trade and the current account: The Harberger-Laursen-Metzler effect,” Journal of Political Economy, 91, 97-125. 
Publisher: Hans-Böckler-Stiftung, Hans-Böckler-Str. 39, 40476 Düsseldorf, Germany Phone: +49-211-7778-331, IMK@boeckler.de, http://www.imk-boeckler.de

IMK Working Paper is an online publication series available at: http://www.boeckler.de/imk 5016.htm

ISSN: $1861-2199$

The views expressed in this paper do not necessarily reflect those of the IMK or the Hans-Böckler-Foundation.

All rights reserved. Reproduction for educational and non-commercial purposes is permitted provided that the source is acknowledged. 